\title{
Job satisfaction, organisational commitment and work engagement in an insurance company
}

\author{
by Norah Sehunoe," Rian Viviers \\ and Claude-Helene Mayer
}

\begin{abstract}
Retaining talented employees and keeping them healthy and well are increasingly important challenges for organisations in the age of the knowledge worker. Organisations are interrogating aspects such as the reasons why some employees are more satisfied, committed and engaged to their organisations than others. Another question is: what should managers do to ensure employee wellness within their organisations? This study explores the relationship between job satisfaction, organisational commitment and work engagement. Spector's (1997) Job Satisfaction Survey, Allen and Meyer's (1990) Organisational Commitment Questionnaire and Schaufeli and Bakker's (2004) Utrecht Work Engagement Scale were administered to a sample of 220 employees from a South African insurance company. The findings show mixed results with regard to significant correlations between job satisfaction, organisational commitment and work engagement. The majority of the findings suggest that there are significant correlations, of a large and medium effect, between scales, including a number of positive relationships of varying strength between job satisfaction, organisational commitment and selected components of work engagement. The findings could benefit organisations as they could contribute to a better understanding of what motivates their workers, particularly their levels of satisfaction, commitment and engagement, and what the combined effect of these might be on the retention and wellness of employees.
\end{abstract}

Key words: job satisfaction; organisational commitment; work engagement; retention; wellbeing; insurance industry

\section{Introduction}

The age of the knowledge worker is characterised by an increasing employee retention challenge (Lumley, Coetzee, Tladinyane \& Ferreira 2011) and vigorous talent mobility in most industries. Retention challenges are related to employee wellbeing (Rothausen \& Henderson 2014; Radler \& Ryff 2010). Wellbeing is viewed as a predictor of retention (Sears, Shi, Coberley \& Pope 2013) and impacts on business performance (Sears et al 2013). Internationally (Hay 2001) and in South Africa (Pop \& Barkhuizen 2010)

\footnotetext{
Ms Sehunoe is a former student in the Department of Industrial and Organisational Psychology at the University of South Africa.

" Prof Rian Viviers is a member of the Department of Industrial and Organisational Psychology at the University of South Africa.

Prof Claude-Helene Mayer is a visiting professor from Germany.
} 
wellbeing is viewed as strongly related to talent management and retention (Burke \& Cooper 2009).

Wellbeing is positively related to job satisfaction (Judge, Thorensen, Bono \& Patton 2001), work engagement (Bakker \& Leiter 2010; Bakker, Schaufeli, Leiter \& Taris 2008) and organisational commitment (Youssef \& Luthans 2007). In South Africa, job satisfaction, more than work engagement, characterises work-related wellbeing (Narainsamy \& Van der Westhuizen 2013). Further studies have also shown that wellbeing predicts outcomes such as organisational commitment (Diedericks 2012) and that these two constructs are positively related (Mayer, Louw \& Louw 2010).

Research in South Africa has found significant positive relationships between job satisfaction and organisational commitment (Krüger \& Rootman 2010), work engagement and job satisfaction (Rothmann 2008) as well as work engagement and organisational commitment (Simons \& Buitendach 2013). No studies using all three constructs were found in the South African context, however.

In the insurance industry job satisfaction and organisational commitment influence retention (Raina \& Roebuck 2014). Job satisfaction and work engagement have a positive impact on the retention of nurses (Giallonardo, Wong \& Iwasiw 2010), while organisational commitment and work engagement showed that volunteer workers in a non-profit organisation are more likely to remain with the organisation (Vecina, Chacó, Sueiro \& Barrón 2012).

In this study the impact of job satisfaction, organisational commitment and work engagement is investigated to explore the relationship between these phenomena and to consider the possible effect that they have on retention and wellbeing. It is especially important for employee relations practitioners to take note of the findings.

\section{The context}

The insurance industry is highly competitive and rivalry between organisations is fierce (Chan 2002), which leads to decreased employee wellbeing, stress and ill-health (Coetzer \& Rothmann 2007). The United States and other countries have indicated that there is expected to be a shortage of skilled insurance professionals in coming years, owing to the retirement of workers, with a potential talent gap (Cole \& McCullough 2012). The combined effect of demographic, social, economic and market-specific factors (Kwon 2014) contributes to retention challenges. This, coupled with the current "South African brain drain" (Rasool \& Botha 2011), poses a potential risk for many organisations in terms of retention and related factors such as the negative psychological impact on morale in the workplace. The interaction between these dynamics could eventually also impact on the wellbeing of employees and the organisation, which is one of the major issues in South African organisations today (Siebenhagen, Pienaar \& Els 2011).

Because the insurance industry is threatened by a potential talent gap (Cole \& McCullough 2012), it is crucial for international and South African insurance organisations not only to gain insight into the relationship between job satisfaction, organisational commitment and work engagement for the purpose of exploring and developing effective talent-retention strategies, but also to ensure wellbeing in general. Based on the empirical findings on job satisfaction, organisational commitment and work engagement of employees, talent-retention strategies can be formulated, not only for the insurance industry, but for organisations in general. 


\section{Job satisfaction}

Job satisfaction has been studied from different perspectives (Ajzen 2011; Aziri 2011; Nazir, Shah \& Zaman 2013). The popularity of this construct can be attributed to the relevance of job satisfaction to the physical and mental wellbeing of employees (Strümpfer \& De Bruin 2009) and it is defined as a pleasurable or positive emotional state that results from an individual's job or job experience (Alessandri, Veccione, Tisak, Deiana, Caria \& Caprara 2012). It has been related to such variables as turnover, job performance, absenteeism and productivity and all of these impact on the profitability of organisations (Fisher 1998). Additionally, job satisfaction influences the mobilisation of resources and is viewed as a positive organisational behaviour construct (Youssef \& Luthans 2007).

In this study, job satisfaction is approached from the perspective of Spector (1997), who defined job satisfaction as individuals' global single overall feelings about their job and the attitudes they have to various aspects or facets of their job such as rewards, interpersonal interaction and the nature of the job itself. The job satisfaction measurement instrument used for this study was based on the concept of global job satisfaction and was justified by the fact that facets often correlate well with overall job satisfaction (Spector 1997). Spector's (1997) theory distinguished between intrinsic job satisfaction, which occurs as a result of performing work and consequently experiencing feelings of satisfaction, and extrinsic job satisfaction, which is derived from factors relevant to the work environment. Both extrinsic and intrinsic job dimensions influence job satisfaction. It was decided, however, to view and use job satisfaction in this particular study only as an overall global construct and measure, instead of focusing on its different subelements. A strong negative relationship was found between job satisfaction and turnover or turnover intention (Emami, Moradi, Idrus \& Almutairi 2012; Martin 2007; Rahman \& Iqbal 2013).

\section{Organisational commitment}

Organisational commitment refers to attitudes implicit in a stable mind-set towards organisations (Chiu \& Ng 2013; Judeh 2011; Lumley et al 2011; Meyer \& Allen 1997; Obi-Nwosu, Chiamaka \& Tochukwu 2013) and is viewed as the relative strength of an individual's involvement in and commitment to a particular organisation (Allen \& Meyer 1990). Meyer and Allen's (1991) multidimensional conceptualisation of organisational commitment is used in this study, as it integrates normative, continuous and affective commitment to form a three-component model of organisational commitment, comprising a cognitive, affective and conative component. This three-component model has been the subject of most of the empirical research to date as a multidimensional construct (Lumley et al 2011; Martin 2007; Suliman \& Iles 2000).

Affective commitment arises from a sense of emotional attachment, whereas continuance commitment is rooted in a sense of economic necessity; normative commitment stems from a sense of moral obligation to remain in the organisation (Coetzee \& Roythorne-Jacobs 2007; Lumley et al 2011; Meyer \& Allen 1991). Employees experiencing the different components would remain with the organisation for different reasons: those experiencing affective commitment remain because they desire to do so; those experiencing continuance commitment remain because they need to; and those experiencing normative commitment remain because of a sense of obligation to the organisation (Meyer \& Allen 1991). 
Research in the South African context has found that organisational commitment moderates the effect of work stress in organisations (Coetzee \& Rothmann 2005). Since organisational commitment reduces stress and increases wellbeing, committed employees contribute positively to the stability and growth of the organisation (Siu 2002).

\section{Work engagement}

Work engagement has been approached in the literature from two different, but related angles (Bakker 2011; Hassan \& Ahmed 2011; Rothmann 2003; Storm \& Rothmann 2003). In this study, the conceptualisation advocated by Schaufeli, Salanova, González-Roma \& Bakker (2002) was adopted, because it separates engagement from the related concept of burnout and, furthermore, positions engagement as an independent construct. The definition (Schaufeli et al 2002) of work engagement encompasses both an affective and a cognitive aspect. This implies that, in addition to cognition, engagement also involves active utilisation of emotions and feelings (Salanova \& Schaufeli 2008). The definition provided by Schaufeli et al (2002) has three dimensions, namely vigour, dedication and absorption. These components can be analysed separately to accurately detect the strengths and weaknesses that exist in terms of each dimension of work engagement.

Vigour refers to high levels of energy, mental toughness, willingness to exert effort, evidence of fierce resolve in one's work and perseverance (Schaufeli et al 2002). This aspect is conceptually related to work motivation, but differs from it in that work engagement is more stable over time (Mauno, Kinnunen \& Ruokolainen 2007; Schaufeli et al 2002). Dedication is evidenced by the intense personal importance of and passion for work and the experience of pride, stimulation and encouragement about work and is conceptually comparable to job involvement (Mauno et al 2007; Schaufeli et al 2002). Absorption is about the experience of being blissfully engrossed by work, being keen and possibly having an unconscious attachment to work, with little prospect for derailment or disruption (Mauno et al 2007; Schaufeli et al 2002). Work engagement has been associated with positive employee attitudes, which influence job satisfaction, increase organisational commitment and decrease intention to resign (Bakker 2011; Demerouti, Bakker, Nachreiner \& Schaufeli 2001; Hassan \& Ahmed 2011).

\section{Integration}

The three presented constructs have been researched from both the individual and the organisational perspective and the implications these have for retention strategies (Chiu \& Ng 2013; Coetzee, Schreuder \& Tladinyane 2007; Folami \& Bline 2012; Greenhaus, Callanan \& Godshalk 2000; Kanye \& Crous 2007; Lumley et al 2011; ObiNwosu et al 2013). Generally, all three constructs are related to wellbeing within organisations.

Research indicated that overall job satisfaction was a significant predictor of organisational commitment (Chiu \& Ng 2013; Judeh 2011; Rutherford, Boles, Hamwi, Madupalli \& Rutherford 2009). Strong positive relationships were found between job satisfaction and organisational commitment (Ayeni \& Phopoola 2007; Kotze \& Roodt 2005). Job satisfaction was found to be determined mainly by how well the organisation met employees' expectations. Research results indicate that satisfied employees tend to be committed to an organisation and employees who are satisfied and committed are 
more likely to attend work, stay with an organisation, arrive at work on time, perform well and engage in behaviour helpful to the organisation (Aamodt 2007; Kumar \& Singh 2011; Oshagbemi 2000; Rahman \& lqbal 2013; Rutherford et al 2009).

Work engagement has had significant effects on work-related attitudes and behavioural outcomes such as job satisfaction, turnover intention and performance through its mediating role between the aforementioned antecedents and outcomes (Bakker 2011; Judeh 2011). Saks (2006) found that work engagement was positively related to employees' job satisfaction and negatively related to turnover intention. Schaufeli and Bakker (2004) also demonstrated that work engagement influenced turnover intention by mediating the relationship with job resources.

Work engagement has been found to be positively related to organisational commitment and negatively related to intention to resign and is believed to be related to job performance and extra-role behaviour as well (Bakker 2011; Hassan \& Ahmed 2011; Judeh 2011; Schaufeli \& Bakker 2004). In this regard, Schaufeli and Bakker (2004) note that engaged employees are likely to have a greater attachment to their organisation and are less likely to leave their organisation and therefore employees who continue to engage themselves do so because of the continuation of favourable reciprocal exchanges.

\section{Problem statement, objective and hypothesis}

Research on job satisfaction, organisational commitment and work engagement can be of value in selection, placement, development, reward and retention practices (Bakker \& Leiter 2010; Coetzee \& Schreuder 2009; Ferreira 2012; Meyer \& Allen 1997; Spector 1997). This article contributes to previously published research on different combinations of these constructs in the South African context by using all three in the same study and filling the void of context-specific (insurance industry) quantitative studies referring to the three related constructs.

The objective of this investigation was to assess the interrelationships between job satisfaction, work engagement and organisational commitment in relation to a sample of employees in an insurance organisation in South Africa. The study further aims to determine whether the different genders, races/ethnicities, age groups and individuals with different levels of education experience job satisfaction, work engagement and organisational commitment differently.

It is expected that positive relationships between job satisfaction, work engagement and organisational commitment will be found to exist. Further, it is presumed that job satisfaction and work engagement would act as strong predictors for organisational commitment within this sample. Finally, it is also expected that different genders, races/ethnicities, age groups and individuals with various levels of education will experience different levels of job satisfaction, work engagement and organisational commitment within this sample.

The following hypotheses have therefore been formulated for this study:

$\mathrm{H}_{1}$ : Positive relationships exist between job satisfaction and the components of work engagement (vigour, dedication, absorption) and organisational (affective, continuance and normative) commitment.

$\mathrm{H}_{2 \mathrm{a}}$ : Job satisfaction predicts affective, continuance and normative commitment.

$\mathrm{H}_{2 \mathrm{~b}}$ : Vigour, dedication and absorption predict affective, continuance and normative commitment. 
$\mathrm{H}_{3 \mathrm{a}}$ : A statistically significant difference in the experience of job satisfaction between genders, races/ethnicities, age groups and levels of qualification exists.

$\mathrm{H}_{3 \mathrm{~b}}$ : A statistically significant difference in the experience of work engagement (vigour, dedication, absorption) between genders, races/ethnicities, age groups and levels of qualification exists.

$\mathrm{H}_{3 \mathrm{c}}$ : A statistically significant difference in the experience of organisational commitment (affective, continuance and normative) between genders, races/ethnicities, age groups and level of qualification exists.

\section{Research method}

\subsection{Research approach}

This study employed a quantitative cross-sectional survey-based research design in order to achieve the primary objectives. According to Shaughnessy, Zechmeister and Zechmeister (2003), this type of design allows for multiple samples to be drawn from the population at a single time-stamp. This design is effective when one aims to determine relationships and to infer predictability.

\subsection{Research participants}

A non-probability, convenience sampling strategy was employed to collect the data. The sample $(n=220)$ was drawn from all permanent employees $(\mathrm{N}=380)$ at a South African insurance company. A $57.89 \%$ response rate was obtained. The biographical information of the sampled participants is presented in Table 1.

Table 1

Biographical characteristics of the sample $(n=220)$

\begin{tabular}{|c|c|c|c|}
\hline Item & Category & $\begin{array}{l}\text { Frequency } \\
(f)\end{array}$ & $\begin{array}{c}\text { Percentage } \\
(\%)\end{array}$ \\
\hline \multirow{2}{*}{ Gender } & Male & 71 & 32.3 \\
\hline & Female & 149 & 67.7 \\
\hline \multirow{4}{*}{ Race } & African & 45 & 20.5 \\
\hline & Coloured & 32 & 14.5 \\
\hline & Indian & 36 & 16.4 \\
\hline & White & 107 & 48.6 \\
\hline \multirow{5}{*}{ Age } & 30 years and younger & 62 & 28.2 \\
\hline & $31-35$ & 34 & 15.5 \\
\hline & $36-45$ & 48 & 21.8 \\
\hline & $46-55$ & 61 & 27.7 \\
\hline & 56 years and older & 15 & 6.8 \\
\hline \multirow{4}{*}{$\begin{array}{l}\text { Qualification } \\
\text { level }\end{array}$} & Grade 12 & 119 & 54.1 \\
\hline & Diploma/Degree & 82 & 37.3 \\
\hline & Honours/B-Tech & 13 & 5.9 \\
\hline & Master's+ & 6 & 2.7 \\
\hline \multirow{5}{*}{$\begin{array}{l}\text { Years of } \\
\text { service }\end{array}$} & Less than 1 year & 92 & 41.8 \\
\hline & $1-4$ & 76 & 34.5 \\
\hline & $5-6$ & 15 & 6.8 \\
\hline & $7-10$ & 8 & 3.6 \\
\hline & More than 10 years & 29 & 13.2 \\
\hline
\end{tabular}


The majority of the sample was made up of white (48.6\%) females $(67.7 \%)$, who were under 30 years of age $(28.2 \%)$. Further, these individuals held at least a Grade 12 $(54.1 \%)$ and were employed for less than a year $(41.8 \%)$ within the insurance company.

\subsection{Measuring instruments}

The following measuring instruments were employed as part of this study:

A biographical questionnaire was used in order to obtain data relating to participants' gender, ethnicity/race, age, level of qualification and years of service within the organisation.

The 36-item Job Satisfaction Survey (JSS, Spector 1997) was employed to measure respondents' level of overall job satisfaction. The responses were rated on a six-point Likert scale ranging from 1 ("Disagree very much") to 6 ("Agree very much"). Examples of the items include: "I feel I am being paid a fair amount for the work I do", "I like the people I work with", and "My supervisor is unfair to me". The reliability of the JSS was evaluated in terms of internal consistency (reliability), which ranged from 0.60 to 0.91 in various studies (Lumley et al 2011; Spector 1997).

The 24-item Organisational Commitment Questionnaire (OCQ, Meyer \& Allen 1997) was used to measure respondents' level of organisational commitment. The OCQ is a multi-dimensional measure, which measures three components of organisational commitment: affective commitment ("I really feel as if this organisation's problems are my own"), continuance commitment ("It wouldn't be too costly for me to leave my organisation now") and normative commitment ("I think that people these days move from company to company too often"), on a seven-point Likert scale ranging from 1 ("Strongly agree") to 7 ("Strongly disagree"). In South African studies the OCQ produced acceptable levels of internal consistency ranging from 0.79 to 0.89 (Dwyer 2001; Field \& Buitendach 2011; Kwela 2001; Van Dyk \& Coetzee 2012).

The 17-item Utrecht Work Engagement Scale (UWES, Schaufeli et al 2002) was utilised to measure employees' level of work engagement. The UWES measures three components of work engagement, namely vigour ("At my job I feel strong and vigorous"), dedication ("At my work I always persevere, even when things do not go well"), absorption ("I am immersed in my work"), on a seven-point Likert scale ranging from 1 ("Never") to 7 ("Always"). The UWES has been used extensively in the South African context and produced acceptable levels of internal consistency ranging from 0.65 to 0.96 on the various subscales (Coetzer \& Rothmann 2007; Field \& Buitendach 2011).

\subsection{Research procedure}

Permission to conduct the research was obtained from the management of the participating insurance company. The HR director sent an e-mail to all employees explaining the purpose of the study and the potential risks/benefits as well as outlining the roles, rights and responsibilities of the various stakeholders. Employees were requested to voluntarily participate in the completion of an online questionnaire (LimeSurvey). An electronic link was provided in the e-mail, which directed potential respondents to the survey instruments. In order to ensure the confidentiality of the participants, full names were not required for the survey; however, they had to complete a biographical questionnaire. 


\subsection{Statistical analysis}

Statistical analysis was carried out by means of the SPSS v.22 (SPSS 2014) statistical analysis software. Descriptive statistics (means, standard deviations, skewness and kurtosis) was used to describe the data. A cut-off of 1.00 for both skewness and kurtosis were set as measures of normality (Field 2009). The level of internal consistency was determined through the use of the Cronbach co-efficient. Nunnally (1978) suggested 0.60 as a recommended guideline for determining the level of internal consistency of a measure.

Based on the distribution of the data, either Pearson's product-moment correlation or Spearman's rho was used to determine the relationship among the variables. A statistical significance level for the correlations was set at the suggested $p<0.01$ (Field 2009). Further, the suggested cut-off point of 0.30 (medium effect) and 0.50 (large effect) were utilised in order to determine the level of practical significance (Field 2009).

Stepwise hierarchical multiple regression analyses were carried out to determine the proportion of variance in organisational commitment declared by job satisfaction and work engagement. Practical significance was represented by Steyn's (2002) effect sizes $\left(0.35>\right.$ large effect) and was determined through the following formula: $f^{2}=R^{2}$ / $\left(1-R^{2}\right)$.

Both univariate analysis of variance (ANOVA) and multivariate analysis of variance (MANOVA) were used to determine the significance of differences between job satisfaction, work engagement and organisational commitment of the different genders, races, ages and levels of education. Wilks' lambda was employed for both the ANOVA and MANOVA in order to determine whether a statistically significant difference exists between job satisfaction, work engagement and organisational commitment and the various biographical variables. Here, a Bonferroni-type adjustment was introduced in order to control for inflated Type I errors.

\section{Results}

The results of the various analyses are presented below. First, the descriptive statistics and correlation results are presented. Second, the results of the stepwise multiple regressions are discussed. Third, the differences among the biographical data and the measured variables in this study are presented.

\subsection{Descriptive statistics and correlations}

Table 2 provides an overview of the descriptive statistics, Cronbach's alpha and correlation coefficients between the variables. The results indicated that all measuring instruments employed in this study comply with the requirements for internal consistency as Cronbach's alpha ranges from 0.62 to 0.93 (Nunnally 1978). Further, the measuring instruments share many properties associated with normal distribution with the exception of vigour $(S=-1.02 ; b=0.92)$, dedication $(S=-1.40 ; b=2.43)$ and absorption $(S=-1.08 ; b=1.28)$. As such, both Pearson's correlations (normally distributed) and Spearman's rho (non-normally distributed) were employed to determine relationships between the variables.

The results confirmed statistically significant relationships with a large effect between affective commitment and job satisfaction ( $r=0.69 ; p<0.01)$, dedication and job satisfaction $(r=0.50 ; p<0.01)$, dedication and vigour $(r=0.80 ; p<0.01)$, absorption and vigour $(r=073 ; p<0.01)$ as well as absorption and dedication $(r=0.70 ; p<0.01)$. 
Further, statistically significant results with a medium effect were found between affective commitment and normative commitment $(r=0.48 ; p<0.01)$, vigour $(r=0.40$; $p<0.01)$, dedication $(r=0.40 ; p<0.01)$ and absorption $(r=0.31 ; p<0.01)$. Similarly, normative commitment correlated statistically significantly with continuance commitment $(r=0.48 ; p<0.01)$, job satisfaction $(r=0.47 ; p<0.01)$, vigour $(r=0.33 ; p$ $<0.01)$, dedication $(r=0.38 ; p<0.01$ ) and absorption $(r=0.35 ; p<0.01)$ with a medium effect. Finally, job satisfaction correlated statistically significantly with vigour $(r$ $=0.44 ; p<0.01)$ and absorption $(r=0.35 ; p<0.01)$ with a medium effect. Hypothesis 1 is therefore partially accepted.

\section{Table 2}

Descriptive statistics and alpha coefficients of job satisfaction, work engagement and organisational commitment

\begin{tabular}{|c|c|c|c|c|c|c|c|c|c|c|c|}
\hline Item & Mean & SD & Skewness & Kurtosis & $\alpha$ & 1 & 2 & 3 & 4 & 5 & 6 \\
\hline $\begin{array}{l}\text { Affective } \\
\text { commitment }\end{array}$ & 4.50 & 0.94 & -0.23 & -0.79 & 0.81 & & & & & & \\
\hline $\begin{array}{l}\text { Continuance } \\
\text { commitment }\end{array}$ & 3.71 & 0.81 & 0.07 & -0.50 & 0.62 & $0.20^{+}$ & & & & & \\
\hline $\begin{array}{l}\text { Normative } \\
\text { commitment }\end{array}$ & 3.49 & 0.98 & -0.52 & -0.63 & 0.87 & $0.48^{+*}$ & $0.48^{+^{*}}$ & & & & \\
\hline $\begin{array}{l}\text { Job } \\
\text { satisfaction }\end{array}$ & 4.11 & 0.74 & -0.05 & -0.53 & 0.93 & $0.69^{+* *}$ & 0.15 & $0.47^{+*}$ & & & \\
\hline Vigour & 5.85 & 0.93 & -1.02 & 0.92 & 0.81 & $0.40^{+*}$ & 0.16 & $0.33^{+*}$ & $0.44^{+*}$ & & \\
\hline Dedication & 5.98 & 1.06 & -1.40 & 2.43 & 0.88 & $0.40^{+*}$ & 0.17 & $0.38^{+*}$ & $0.50^{+\times x}$ & $0.80^{+\times x}$ & \\
\hline Absorption & 5.82 & 0.97 & -1.08 & 1.28 & 0.77 & $0.31^{+^{*}}$ & 0.17 & $0.35^{+^{*}}$ & $0.35^{+*}$ & $0.73^{+x x}$ & $0.70^{+"}$ \\
\hline
\end{tabular}

+ Statistically significant $(p<0.01)$

* Correlation is practically significant $r<0.30$ (medium effect)

** Correlation is practically significant $r<0.50$ (large effect)

\subsection{Inferential statistics}

Table 3

Multiple regression analysis with affective commitment as dependent variable

\begin{tabular}{|c|c|c|c|c|c|c|c|c|c|c|c|}
\hline \multirow{2}{*}{ Model } & & \multicolumn{2}{|c|}{$\begin{array}{l}\text { Unstandardised } \\
\text { coefficients }\end{array}$} & \multirow{2}{*}{$\begin{array}{c}\text { Standardised } \\
\text { coefficients } \\
\text { BETA }(\beta) \\
\end{array}$} & \multirow[t]{2}{*}{$t$} & \multirow[t]{2}{*}{$P$} & \multirow[t]{2}{*}{$F$} & \multirow[t]{2}{*}{$R$} & \multirow[t]{2}{*}{$R^{2}$} & \multirow{2}{*}{$\Delta R^{2}$} & \multirow[t]{2}{*}{$f^{2}$} \\
\hline & & B & SE & & & & & & & & \\
\hline \multirow[b]{2}{*}{1} & (Constant) & 0.92 & 0.26 & & 3.51 & 0.00 & 189.97 & 0.68 & 0.47 & 0.47 & 0.89 \\
\hline & $\begin{array}{l}\text { Job } \\
\text { satisfaction }\end{array}$ & 0.87 & 0.06 & 0.68 & 13.78 & 0.00 & & & & & \\
\hline \multirow{5}{*}{2} & (Constant) & 0.57 & 0.34 & & 1.68 & 0.00 & 48.52 & 0.69 & 0.48 & 0.01 & 0.92 \\
\hline & $\begin{array}{l}\text { Job } \\
\text { satisfaction }\end{array}$ & 0.84 & 0.07 & 0.66 & 11.57 & 0.00 & & & & & \\
\hline & Vigour & 0.14 & 0.09 & 0.14 & 1.47 & 0.14 & & & & & \\
\hline & Dedication & -0.09 & 0.08 & -0.10 & -1.06 & 0.29 & & & & & \\
\hline & Absorption & 0.03 & 0.08 & 0.03 & 0.43 & 0.67 & & & & & \\
\hline
\end{tabular}

Table 3 summarises the results of the stepwise multiple regression analyses with job satisfaction and the components of work engagement (vigour, dedication and absorption) as predictors of affective commitment. The first step of the regression analysis produced a statistically significant model in which $\mathrm{F}_{(1,128)}=189.97(p=0.00)$ and approximately $47 \%$ of the variance is accounted for. Within the first step of the regression analysis, job satisfaction acted as a strong predictor $(\beta=0.68 ; t=13.78 ; p \leq$ 
0.01) of affective commitment. In step two of the regression analysis, the components of work engagement (vigour, dedication and absorption) were entered and produced a statistically significant model $\left(F_{4,215}=48.52 ; p=0.00 ; \Delta R^{2}=0.01\right)$, which accounted for a $1 \%$ change in the overall variance. Here only job satisfaction $(\beta=0.66 ; t=11.57 ; p \leq$ 0.01 ) seemed to still predict affective commitment. Vigour, dedication and absorption ( $p$ $>0.01$ ) were not significant predictors of affective commitment.

Table 4

Multiple regression analysis with continuance commitment as dependent variable

\begin{tabular}{|c|c|c|c|c|c|c|c|c|c|c|c|}
\hline \multirow[t]{2}{*}{ Model } & & \multicolumn{2}{|c|}{$\begin{array}{c}\text { Unstandardised } \\
\text { coefficients }\end{array}$} & \multirow{2}{*}{$\begin{array}{c}\begin{array}{c}\text { Standardised } \\
\text { coefficients }\end{array} \\
\text { BETA }(\beta)\end{array}$} & \multirow[t]{2}{*}{$t$} & \multirow[t]{2}{*}{$P$} & \multirow[t]{2}{*}{$F$} & \multirow[t]{2}{*}{$R$} & \multirow[t]{2}{*}{$R^{2}$} & \multirow{2}{*}{$\Delta R^{2}$} & \multirow[t]{2}{*}{$f^{2}$} \\
\hline & & B & SE & & & & & & & & \\
\hline \multirow[b]{2}{*}{1} & (Constant) & 3.05 & 0.31 & & 9.81 & 0.00 & 4.75 & 0.15 & 0.02 & 0.02 & 0.02 \\
\hline & $\begin{array}{l}\text { Job } \\
\text { satisfaction }\end{array}$ & 0.16 & 0.07 & 0.15 & 2.17 & 0.00 & & & & & \\
\hline \multirow{5}{*}{2} & (Constant) & 2.64 & 0.40 & & & 0.04 & 2.57 & 0.21 & 0.05 & 0.03 & 0.05 \\
\hline & $\begin{array}{l}\text { Job } \\
\text { satisfaction }\end{array}$ & 0.07 & 0.09 & 0.07 & 0.84 & 0.40 & & & & & \\
\hline & Vigour & -0.07 & 0.11 & -0.08 & -0.66 & 0.51 & & & & & \\
\hline & Dedication & 0.13 & 0.10 & 0.16 & 1.29 & 0.20 & & & & & \\
\hline & Absorption & 0.08 & 0.09 & 0.09 & 0.86 & 0.39 & & & & & \\
\hline
\end{tabular}

Table 4 summarises the results of the stepwise multiple regression analyses with job satisfaction and the components of work engagement (vigour, dedication and absorption) as predictors of continuance commitment. The first step of the regression analysis produced a statistically significant model in which $\mathrm{F}_{(1,128)}=4.75(p=0.00)$ and which accounts for approximately $2 \%$ of the variance. Within the first step of the regression analysis, job satisfaction acted as a menial predictor $(\beta=0.15 ; t=2.17 ; p \leq$ 0.01) of continuance commitment. In step two of the regression analysis, the components of work engagement (vigour, dedication and absorption) were entered, but this did not produce a statistically significant model $\left(F_{4,215}=2.57 ; p=0.04 ; \Delta R^{2}=0.03\right)$. Therefore, neither work engagement nor job satisfaction (in combination) acted as predictors for continuance commitment within this sample.

Table 5

Multiple regression analysis with normative commitment as dependent variable

\begin{tabular}{|c|c|c|c|c|c|c|c|c|c|c|c|}
\hline \multirow[t]{2}{*}{ Model } & & \multicolumn{2}{|c|}{$\begin{array}{c}\text { Unstandardised } \\
\text { coefficients }\end{array}$} & \multirow{2}{*}{$\begin{array}{c}\begin{array}{c}\text { Standardised } \\
\text { coefficients }\end{array} \\
\text { BETA }(\beta)\end{array}$} & \multirow[t]{2}{*}{$T$} & \multirow[t]{2}{*}{$P$} & \multirow[t]{2}{*}{$F$} & \multirow[t]{2}{*}{$R$} & \multirow[t]{2}{*}{$R^{2}$} & \multirow[t]{2}{*}{$\Delta R^{2}$} & \multirow[t]{2}{*}{$f^{2}$} \\
\hline & & B & SE & & & & & & & & \\
\hline \multirow[t]{2}{*}{1} & (Constant) & 0.92 & 0.33 & & 2.75 & 0.01 & 61.33 & 0.47 & 0.22 & 0.22 & 0.28 \\
\hline & $\begin{array}{l}\text { Job } \\
\text { satisfaction }\end{array}$ & 0.63 & 0.08 & 0.47 & 7.83 & 0.00 & & & & & \\
\hline \multirow[t]{5}{*}{2} & (Constant) & 0.04 & 0.42 & & 0.09 & 0.93 & 20.00 & 0.52 & 0.27 & 0.05 & 0.37 \\
\hline & $\begin{array}{l}\text { Job } \\
\text { satisfaction }\end{array}$ & 0.48 & 0.09 & 0.36 & 5.30 & 0.00 & & & & & \\
\hline & Vigour & -0.05 & 0.12 & -0.05 & -0.44 & 0.66 & & & & & \\
\hline & Dedication & 0.10 & 0.10 & 0.11 & 1.06 & 0.29 & & & & & \\
\hline & Absorption & 0.20 & 0.09 & 0.19 & 2.09 & 0.04 & & & & & \\
\hline
\end{tabular}

Finally, table 5 summarises the results of the stepwise multiple regression analyses with job satisfaction and the components of work engagement (vigour, dedication and absorption) as predictors of normative commitment. The first step of the regression analysis produced a statistically significant model in which $\mathrm{F}_{(1,128)}=61.33(p=0.00)$ and which accounts for approximately $22 \%$ of the variance. Within the first step of the 
regression analysis, job satisfaction predicted $(\beta=0.47 ; t=7.83 ; p \leq 0.01)$ normative commitment. In step two of the regression analysis, the components of work engagement (vigour, dedication and absorption) were entered, but this did not produce statistically significant results $\left(F_{4,215}=20 ; p=0.93 ; \Delta R^{2}=0.05\right)$. Therefore, neither work engagement nor job satisfaction (in combination) acted as predictors for normative commitment within this sample. Hypothesis $2_{\mathrm{a}}$ is therefore accepted. However, hypothesis $2_{\mathrm{b}}$ is therefore not accepted.

\subsection{Univariate and multivariate analysis of variance}

MANOVA (multivariate analysis of variance) was used to determine differences between gender, race, age and level of qualification in relation to organisational commitment and work engagement. Similarly, ANOVA (univariate analysis of variance) was used to determine the differences between job satisfaction and gender, race, age and level of qualification within this sample. Wilks' lambda was employed to determine whether a statistically significant difference exists between organisational commitment and the various biographical variables.

Table 6

MANOVA - Differences in organisational commitment between gender, race, age and level of qualification

\begin{tabular}{|l|c|c|c|c|c|}
\hline \multicolumn{1}{|c|}{ Variable } & Value & $\boldsymbol{F}$ & $\boldsymbol{D f}$ & $\boldsymbol{p}$ & $\begin{array}{c}\text { Partial Eta } \\
\text { squared }\end{array}$ \\
\hline Gender & 0.99 & 0.66 & 3 & 0.58 & 0.01 \\
\hline Race & 0.97 & 0.82 & 9 & 0.60 & 0.01 \\
\hline Age & 0.93 & 1.27 & 12 & 0.23 & 0.02 \\
\hline Level of qualification & 0.97 & 0.69 & 9 & 0.72 & 0.01 \\
\hline
\end{tabular}

$p \leq 0.05=$ statistically significant

Table 6 shows that there was no statistically significant difference on the combined dependent variable, organisational commitment, between the different genders $\left(F_{(3,215)}\right.$ $\left.=0.66 ; p>0.01 ; \lambda=0.99 ; \eta \rho^{2}=0.01\right)$, races $\left(F_{(3,215)}=0.82 ; p>0.01 ; \lambda=0.97 ; \eta \rho^{2}=\right.$ $0.01)$, ages $\left(F_{(3,215)}=1.27 ; p>0.01 ; \lambda=0.93 ; n \rho^{2}=0.02\right)$ or levels of qualification $\left(F_{(3,}\right.$ 215) $\left.=0.69 ; p>0.01 ; \lambda=0.97 ; n \rho^{2}=0.01\right)$.

Table 7

MANOVA - Differences in work engagement between gender, race, age and level of qualification

\begin{tabular}{|l|c|c|c|c|c|}
\hline \multicolumn{1}{|c|}{ Variable } & Value & $\boldsymbol{F}$ & $\boldsymbol{D f}$ & $\boldsymbol{p}$ & $\boldsymbol{\eta} \boldsymbol{p}^{\mathbf{2}}$ \\
\hline Gender & 0.99 & 1.00 & 3 & 0.39 & 0.01 \\
\hline Race & 0.98 & 0.46 & 9 & 0.90 & 0.01 \\
\hline Age & 0.93 & 1.36 & 12 & 0.18 & 0.03 \\
\hline Level of qualification & 0.93 & 1.66 & 9 & 0.10 & 0.02 \\
\hline
\end{tabular}

$p \leq 0.05=$ statistically significant

Similarly, Table 7 shows that there was no statistically significant difference on the combined dependent variable, work engagement, between different genders $\left(F_{(3,214)}=\right.$ $\left.1.00 ; p>0.01 ; \lambda=0.99 ; n \rho^{2}=0.01\right)$, races $\left(F_{(3,214)}=0.46 ; p>0.01 ; \lambda=0.98 ; n \rho^{2}=0,01\right)$, ages $\left(F_{(3,214)}=1.36 ; p>0.01 ; \lambda=0.93 ; \eta \rho^{2}=0.03\right)$ or levels of qualification $\left(F_{(3,214)}=\right.$ $\left.1.66 ; \mathrm{p}>0.01 ; \lambda=0.93 ; n \rho^{2}=0.02\right)$. 
Table 8

ANOVA -Differences in job satisfaction between genders

\begin{tabular}{|c|c|c|c|c|}
\hline Item & Males & Females & $\boldsymbol{P}$ & $\begin{array}{c}\text { Partial Eta } \\
\text { squared }\end{array}$ \\
\hline Job satisfaction & 4.23 & 4.05 & 0.10 & 0.01 \\
\hline
\end{tabular}

* $p \leq 0.05=$ statistically significant

Table 9

ANOVA -Differences in job satisfaction between races

\begin{tabular}{|c|c|c|c|c|c|c|}
\hline Item & African & Coloured & Indian & White & $\boldsymbol{P}$ & $\begin{array}{c}\text { Partial Eta } \\
\text { squared }\end{array}$ \\
\hline Job satisfaction & 4.03 & 4.16 & 3.99 & 4.16 & 0.54 & 0.01 \\
\hline
\end{tabular}

Table 10

ANOVA - Differences in job satisfaction between ages

\begin{tabular}{|c|c|c|c|c|c|c|c|}
\hline Item & $\begin{array}{c}<\mathbf{3 0} \\
\text { years }\end{array}$ & $\begin{array}{c}\mathbf{3 1} \text { to } \mathbf{3 5} \\
\text { years }\end{array}$ & $\begin{array}{c}\mathbf{3 6} \text { to } \mathbf{4 5} \\
\text { years }\end{array}$ & $\begin{array}{c}\mathbf{4 6} \text { to } \mathbf{5 5} \\
\text { years }\end{array}$ & $\mathbf{> 5 6}$ years & $\boldsymbol{P}$ & $\begin{array}{c}\text { Partial Eta } \\
\text { squared }\end{array}$ \\
\hline Job satisfaction & 4.14 & 4.10 & 3.99 & 4.19 & 4.02 & 0.69 & 0.01 \\
\hline
\end{tabular}

Table 11

ANOVA - Differences in job satisfaction between level of education

\begin{tabular}{|c|c|c|c|c|c|c|}
\hline Item & $\begin{array}{c}\text { Grade } \\
\mathbf{1 2}\end{array}$ & $\begin{array}{c}\text { Diploma / } \\
\text { degree }\end{array}$ & $\begin{array}{c}\text { Hons / } \\
\text { B.Tech }\end{array}$ & Master's & $\boldsymbol{P}$ & $\begin{array}{c}\text { Partial Eta } \\
\text { squared }\end{array}$ \\
\hline Job satisfaction & 4.07 & 4.10 & 4.32 & 4.44 & 0.46 & 0.01 \\
\hline
\end{tabular}

Tables 8 to 11 indicate that no statistically significant differences $(p>0.01)$ between job satisfaction and gender, race, age groups or levels of education exist.

Accordingly, hypothesis $3_{a, b} \& \mathrm{c}$ is not accepted.

\section{Discussion}

The objective of this study was to investigate the relationships between job satisfaction, organisational commitment and work engagement within an insurance company, as well as to determine whether job satisfaction and work engagement would act as predictors of organisational commitment within this sample of employees. A further aim was to determine whether there are significant differences in the experiences of job satisfaction, work engagement and organisational commitment between selected biographical data groups.

Firstly, the results indicated that the three measuring instruments employed in this study, namely job satisfaction, organisational commitment and work engagement comply with the requirements for internal consistency (Nunnally 1978). The reliability coefficients of the sample were in agreement with those determined in previous research (Coetzer \& Rothmann 2007; Lumley et al 2011; Pillay 2008; Schaufeli et al 2002; Schaufeli \& Bakker 2004; Storm \& Rothmann 2003; Suliman \& lles 2002). The measures used were therefore regarded as reliable for this study.

From the correlational data it can be concluded that mixed results were obtained with regard to significant correlations between job satisfaction and the organisational commitment and work engagement constructs. The majority of findings suggest significant correlations of large and medium effect between scales. It therefore seems that varying degrees of positive relationships exist between job satisfaction and the components of work engagement (vigour, dedication and absorption) and 
organisational (affective, continuance and normative) commitment. Hypothesis 1 is, therefore, partially accepted. Similar positive relationships between job satisfaction and organisational commitment were reported by Carmeli and Freund (2004), Lumley et al (2011), Martin and Roodt (2008), Peng, Li, Zhang, Tian, Miao, Xiao and Zhang (2014) and Savaneviciene and Stankeviciute (2011); between job satisfaction and work engagement (Giallonardo, Wong \& Iwasiw 2010; Salanova, Agut \& Peiro 2005; Xanthopoulou, Bakker, Demerouti \& Schaufeli 2009); and also between organisational commitment and work engagement (Cho, Laschinger \& Wong 2006; Hakanen, Schaufeli \& Ahola 2008). These positive relationships between the constructs indicate that employees who experience some degree of job satisfaction in the organisation will also have a level of commitment to the organisation and would be engaged with their work. This implies being satisfied with the current job (Spector 1997); displaying involvement in and commitment to a particular organisation (Allen \& Meyer 1990); and showing a stable work motivation, attaching intense personal importance to work, having a passion for work and being blissfully engrossed by work (Schaufeli et al 2002). Such a state of contentment with current employment can ultimately impact on intention to stay in the current job (retention) and also on general wellbeing in the work context, as it is positively related to job satisfaction (Judge, Thorensen, Bono \& Patton 2001), work engagement (Bakker \& Leiter 2010; Bakker, Schaufeli, Leiter \& Taris 2008) and organisational commitment (Youssef \& Luthan 2007).

It was further presumed that job satisfaction and work engagement would act as strong predictors for organisational commitment for this sample in the insurance industry. The results of the stepwise multiple regression analyses indicated that job satisfaction acted as a strong predictor of affective commitment. Similar findings were reported by Brunetto, Teo, Shacklock and Farr-Wharton (2012) and Lumley et al (2011). Vigour, dedication and absorption as components of work engagement produced a statistically significant model. It emerged that only job satisfaction still seemed to predict affective commitment. Neither vigour nor dedication or absorption materialised as significant predictors of affective commitment. The implication of this is that any individual who experiences job satisfaction on the affective level feels emotionally attached to the organisation. According to Allen and Meyer (1990), strongly committed employees identify with the organisation, enjoy the membership of the organisation and are usually emotionally involved in the organisation. Previous research (Spector 2008; Mathieu \& Zajac 1990; Arzu Wasti 2003) established that affective commitment has the most consistent and also the strongest positive impact on desirable and advantageous work outcomes. According to Mathieu and Zaiac (1990) and Siu (2002), a strong organisational commitment has the additional positive effect of providing employees with stability and feelings of belonging and thereby helping to reduce stress, which could enhance the wellbeing of employees.

The results of the stepwise multiple regression analyses indicated that job satisfaction acted as a strong predictor of continuance commitment. In contrast to this finding, Lumley et al (2011) and Meyer, Allen and Smith (1993) found a negative relationship between job satisfaction and continuance commitment and no prediction by job satisfaction of continuance commitment. This finding is interesting as literature indicates that job satisfaction mostly do not predict continuance commitment commitment because an employee must stay due to personal knowledge and insight about the consequences of leaving the organisation (Meyer \& Allen 1991). In this study, job satisfaction predicts continuance commitment in the specific insurance industry. Possible reasons could be the current high unemployment rate in South Africa of $25.5 \%$, with women comprising $52.2 \%$ of the workforce (Statistics South Africa 2015). 
Another factor, based on the particular sample and related to the current high unemployment rate, might be the biographical composition of the majority of the group, namely white $(48.6 \%)$ females $(67.7 \%)$, under 30 years of age $(28.2 \%)$, with only a Grade $12(54.1 \%)$ and employed for less than a year $(41.8 \%)$ at the insurance company. These limiting biographical circumstances could possibly have influenced the continuance commitment of the group's responses. Vigour, dedication and absorption, as components of work engagement, did not produce a statistically significant model. This is in line with findings by Field and Buitendach (2011), who reported that work engagement had statistically significant predictive value for affective organisational commitment only, and not for continuance commitment. It was found that neither work engagement nor job satisfaction (in combination) acted as predictors for continuance commitment within this sample. As continuance commitment entails an understanding of the consequences of leaving the organisation (Meyer \& Allen 1997), it can be concluded that the practical aspects of staying in the organisation (continuance commitment) cannot be predicted by work engagement or any of its components.

Finally, the results of the step-wise multiple regression analyses indicated that job satisfaction acted as a strong predictor of normative commitment. Similar results have been reported by Meyer, Stanley, Herscovitch and Topolnytsky (2002). This is in line with findings by Lumley et al (2011) and Meyer and Allen (1997) that job satisfaction influences normative commitment in the sense that a moral responsibility to continue with the organisation exists among satisfied employees. This kind of commitment can also be linked to improved employee wellbeing, as clarity regarding a moral obligation to remain with the organisation is experienced by the employee. Vigour, dedication and absorption did not produce statistically significant results. Specific research investigating whether work engagement is a predictor of normative commitment could not be found. Simons and Buitendach (2013) only report that work engagement predicts total commitment. Attempts to explain why vigour, dedication and absorption do not predict normative commitment have suggested different possibilities: (1) engagement encompasses both an affective and a cognitive aspect as well as the active utilisation of emotions and feelings regarding engagement in the work and the job at hand (Salanova \& Schaufeli 2008; Schaufeli et al 2002); (2) normative commitment is merely a sense of responsibility to continue employment with a specific organisation (Meyer \& Allen 1997) and a moral view to remain with a specific organisation (March \& Mannari 1977).

Neither work engagement nor job satisfaction (in combination) acted as predictors of normative commitment within this sample. Similar findings could not be found and, based on the discussion above, this aspect does not warrant further discussion. Hypothesis $2 \mathrm{a}$, that job satisfaction predicts affective, continuance and normative commitment is therefore accepted. However, hypothesis $2_{b}$, namely that vigour, dedication and absorption predict affective, continuance and normative commitment is not accepted.

In this study it was expected that a statistically significant difference in the experience of job satisfaction between genders, races/ethnicities, age groups and levels of qualification would exist $\left(\mathrm{H}_{3 a}\right)$. However, the results of the multivariate analysis of variance show that there were no statistically significant differences on the combined dependent variable, organisational commitment, between different genders, races, ages or levels of qualification. Hypothesis $\mathrm{H}_{3 a}$ is therefore not accepted. Previous studies indicated generally inconsistent relationships between job satisfaction and gender (Ghazzawi 2008, Spector 1997), as well as race (Martin \& Roodt 2008). 
Previous studies on job satisfaction and age show that job satisfaction usually increases with age (Spector 2008). The results from this study do not support the results of Lumley et al (2011), who found differences in the levels of job satisfaction in relation to age, race and gender in the South African context; however, the results of Kardam and Rangnekar (2012) do not show any significant differences between job satisfaction and levels of education/qualification.

In $\mathrm{H}_{3 \mathrm{~b}}$ it was assumed that a statistically significant difference in the experience of work engagement (vigour, dedication, absorption) between genders, races/ethnicities, age groups and levels of qualification exists. The results of this study show that there was no statistically significant difference on the combined dependent variable, work engagement, between different genders, races, ages or levels of qualification. Hypothesis $\mathrm{H}_{3 b}$ is therefore not accepted. These results support the results of Barkhuizen and Rothmann (2006) that there are no significant differences between work engagement and age, gender and education.

With regard to hypothesis $\mathrm{H}_{3 \mathrm{c}}$, a statistically significant difference in the experience of organisational commitment (affective, continuance and normative) between genders, races/ethnicities, age groups and levels of qualification exists. A statistically significant difference in the experience of organisational commitment (affective, continuance and normative) between genders, races/ethnicities, age groups and levels of qualification was not found. The hypothesis is therefore not accepted. These results differ from the results found by Lumley et al (2011), who found significant differences between gender, race and organisational commitment.

\section{Limitations of the study}

Although this study provides new insights into job satisfaction, organisational commitment and work engagement, the study is not without its limitations. Firstly, the study was conducted in a single organisation; therefore, the results of the study are not generalisable across other organisations, although the findings might provide insights that will allow employment relations practitioners to take corrective steps in dealing with issues around retention and employee wellbeing. Secondly, the sample did not proportionally represent the South African population in gender, age and race groups, thus further reducing the potential to generalise the results to the diverse South African population. Thirdly, a non-probability convenience sampling strategy, as opposed to a random sampling method, was applied. Finally, the collection of data from self-related questionnaires might have affected the reliability and validity of the data.

\section{Conclusion}

These findings may benefit employment relations practitioners by helping organisations understand their workers, particularly their levels of satisfaction, commitment and engagement and what the combined effect of these might be on the retention of satisfied, committed and engaged employees. The impact of such positive attitudes might not always be measured empirically, but research has shown the effect on employee wellbeing which ultimately benefits the organisation. Hence, customised strategies for improved job satisfaction, organisational commitment and work engagement can be developed by employment relations practitioners to impact positively on the retention of employees and their wellbeing.

As such the following broad guidelines are provided for employment relations practitioners to take note of: 
- Be aware of the general level of job satisfaction, commitment and engagement of employees. This can be measured through scientific instruments such as the ones used in this study.

- Introduce wellness programmes in the organisation to focus on wellness and possible factors that result in a decline in wellness. In this regard, assess the toxic impact of organisational practices on employees and address this issue.

Owing to the limited scope of the study, it is recommended that further studies be undertaken in order to address this limitation. The relationships between job satisfaction, organisational commitment and work engagement and even other related constructs should be studied in multiple industries in South Africa. This would give employment relations practitioners deeper insight into and understanding of the possible causes of and underlying factors in burning issues such as talent management and retention in the current dynamic but turbulent South African business world.

\section{List of references}

Aamodt, MG. 2007. Industrial/organisational psychology: An applied approach. Belmont, CA: Thomson Higher Education.

Ajzen, I. 2011. Job satisfaction, effort and performance: A reasoned action perspective. Contemporary Economics 5(4):32-43.

Alessandri G, Veccione M, Tisak J, Deiana G, Caria S \& Caprara GV. 2012. The utility of positive orientation in predicting job performance and organisational citizenship behaviours. Applied Psychology: An International Review 61(4):669-698.

Allen, NJ \& Meyer, JP. 1990. The measurement and antecedents of affective, continuance and normative commitment to the organisation. Journal of Occupational Psychology 63:1-18.

Arzu Wasti. S. 2003. The influence of cultural values on antecedents of oraanisational commitment: An individual-level analysis. Applied Psychology 52(4):533-554.

Ayeni, CO \& Phopoola, SO. 2007. Work motivation, job satisfaction, and organizational commitment of library personnel in academic and research libraries in Oyo State, Nigeria. Library Philosophy and Practice.

Aziri, B. 2011. Job satisfaction: A literature review. Management Research and Practice 3(4):77-86.

Bakker, AB. 2011. An evidence-based model of work engagement. Association for Psychological Science 20(4):265-269.

Bakker, AB \& Leiter, MP. 2010. Work engagement: A handbook of essential theory and research. New York: Psychology Press.

Bakker, AB, Schaufeli, WB, Leiter, MP \& Taris, TW. 2008. Work engagement: An emerging concept in occupational health psychology. Work \& Stress 22:187-200.

Barkhuizen, N \& Rothmann, S. 2006. Work engagement of academic staff in South African higher education institutions. Management Dynamics 15(1):38-46.

Brunetto, Y, Teo, ST, Shacklock, K \& Farr-Wharton, R. 2012. Emotional intelligence, job satisfaction, well-being and engagement: Explaining organisational commitment and turnover intentions in policing. Human Resource Management Journal 22(4):428-441. 
Burke, RJ \& Cooper, CL. 2009. The peak performing organization. New York: Routledge.

Carmeli, A \& Freund, A. 2004. Work commitment, job satisfaction, and job performance: An empirical investigation. International Journal of Organization Theory and Behavior 7(3):289-309.

Chan, KB. 2002. Coping with work stress, work satisfaction, and social support: An interpretive study of life insurance agents. Asian Journal of Social Science 30(3): 657-685.

Chiu, WYB \& Ng, FF. 2013. Improvement of job satisfaction and organisational commitment through work group identification: An examination of the quantity surveyors in Hong Kong. Australasian Journal of Construction Economics and Building 13(3):80-95.

Cho, J Laschinger, HS \& Wong, C. 2006. Workplace empowerment, work engagement and organizational commitment of new graduate nurses. Nursing Leadership Academy of Canadian Executive Nurses 19(3):43.

Coetzee, M \& Roythorne-Jacobs, H. 2007. Career counselling and guidance in the workplace: A manual for career practitioners. Cape Town: Juta.

Coetzee, M \& Schreuder, D. 2009. Using the Career Orientations Inventory (COI) for measuring internal career orientations in the South African organisational context. SA Journal of Industrial Psychology 35(1):1-14.

Coetzee, M, Schreuder, D \& Tladinyane, R. 2007. Organisational commitment and its relation to career anchors. Southern African Business Review 11(1):65-86.

Coetzee, SE \& Rothmann, S. 2005. Occupational stress, organisational commitment, ill-health of employees at a higher educational institution in South Africa. Journal of Industrial Psychology 31(1):47-54.

Coetzer, WJ \& Rothmann, S. 2007. A psychometric evaluation of measures of affective wellbeing in an insurance company. South African Journal of Industrial Psychology 33(2):7-15.

Cole, CR \& McCullough, KA. 2012. The insurance industry's talent gap and where we go from here. Risk Management and Insurance Review 15(1):107-116.

Demerouti E, Bakker AB, Nachreiner F \& Schaufeli, WB. 2001. The job demandsresources model of burnout. Journal of Applied Psychology 86(3):499-512.

Diedericks, E. 2012. Flourishing of employees in the information technology industry in South Africa. Unpublished doctoral thesis, North West University, Vanderbijlpark, South Africa.

Dwyer, TC. 2001. Employee empowerment within a manufacturing organisation. Unpublished Master's dissertation, Potchefstroom University for Christian Higher Education, Potchefstroom.

Emami, R, Moradi, E, Idrus, D \& Almutairi, DO. 2012. Investigating the relationship between organizational learning culture, job satisfaction and turnover intention in SMEs. International Journal of Innovative Ideas 12(1):8-23.

Ferreira, N. 2012. Hardiness in relation to organisational commitment in the human resource management field. South African Journal of Human Resource Management 10(2):1-10. Available at: DOI: 10.4102/sajhrm.v10i2.418. 
Field, A. 2009. Discovering statistics using SPSS. $2^{\text {nd }}$ edition. London, United Kingdom: Sage.

Field, LK \& Buitendach, JH. 2011. Happiness, work engagement and organisational commitment of support staff at a tertiary education institution in South Africa. SA Journal of Industrial Psychology 37(1):1-10. Available at: DOI:10.4102/sajip.v37i1.946.

Fisher, CD. 1998. Mood and emotions while working - missing pieces of job satisfaction. School of Business Discussion Papers. Paper 64. Queensland: Bond University. Available at: http://epublications.bond.edu.au/discussion_papers/64 (accessed on 10 October 2014).

Folami, L \& Bline, D. 2012. Relationship among job satisfaction, task complexity and organizational context in public accounting. International Review of Business Research Paper 8(4):207-224.

Ghazzawi, I. 2008. Job satisfaction antecedents and consequences: A new conceptual framework and research agenda. The Business Review 11(2):1-10.

Giallonardo, LM, Wong, CA \& Iwasiw, CL. 2010. Authentic leadership of preceptors: Predictor of new graduate nurses' work engagement and job satisfaction. Journal of Nursing Management 18(8):993-1003.

Greenhaus, JH, Callanan, GA \& Godshalk, VM. 2000. Career Management. $3^{\text {rd }}$ edition. Fort Worth: Harcourt.

Hakanen, JJ, Schaufeli, WB \& Ahola, K. 2008. The job demands-resources model: A three-year cross-lagged study of burnout, depression, commitment, and work engagement. Work \& Stress 22(3):224-241.

Hassan, A \& Ahmed, F. 2011. Authentic leadership, trust and work engagement. International Journal of Human and Social Sciences 6(3):164-170.

Hay, M. 2001. Strategies for survival in the war of talent. Career Development International 7(1):52-55.

Judeh, M. 2011. Role ambiguity and role conflict as mediators of the relationship between socialization and organizational commitment. International Business Research 4(3):171-181.

Judge, TA, Thorensen, CJ, Bono, JE \& Patton, GK. 2001. The job satisfaction-job performance relationship: A qualitative and quantitative review. Psychologcal Bulletin 127(3):376-407.

Kanye, B \& Crous, F. 2007. Graduate interns' experiences: A career success orientations approach. SA Journal of Industrial Psychology 33(3):84-93.

Kardam, BL \& Rangnekar, S. 2012. Job satisfaction: Investigating the role of experience \& education. Journal of Arts, Science \& Commerce 4(1):16-22.

Kotze K \& Roodt G. 2005. Factors that affect the retention of managerial and specialist staff: An exploratory study of an employee commitment model. South African Journal of Human Resource Management 3(2):48-55.

Krüger J \& Rootman C. 2010. How do small business managers influence employee satisfaction and commitment? Acta Commercii 10(2):59-72.

Kumar, N \& Singh, V. 2011. Job satisfaction and its correlates. International Journal of Research in Economics \& Social Sciences 1(2):11-24. 
Kwela, SM. 2001. Organisational commitment and job satisfaction of non-academic personnel at a tertiary institution. Unpublished master's dissertation, Potchefstroom University for Christian Higher Education, Vanderbijlpark.

Kwon, WJ. 2014. Human capital risk and talent management issues in the insurance market: Public policy, industry and collegiate education perspectives. Geneva Papers on Risk \& Insurance 39(1):173-196. Available at: DOI: http://dx.doi.org/10.1057/gpp.2013.11.

Lumley, EJ, Coetzee, M, Tladinyane, R \& Ferreira, N. 2011. Exploring the job satisfaction and organisational commitment of employees in the information technology environment. Southern African Business Review 15(1):100-118.

March, R \& Mannari, H. 1977. Organisational commitment and turnover: A prediction study. Administrative Science Quarterly 22:57-67.

Martin, A. 2007. Employee perceptions of organisational commitment, job satisfaction and turnover intentions in a post-merger institution. Unpublished MCom dissertation, University of Johannesburg, Johannesburg.

Martin. A \& Roodt. G. 2008. Percentions of oraanisational commitment. iob satisfaction and turnover intentions in a post-meraer South African tertiary institution. $S A$ Journal of Industrial Psychology 34(1):23-31.

Mathieu, JE \& Zajac, DM. 1990. A review and meta-analysis of the antecedents, correlates. and consequences of organizational commitment. Psychological Bulletin 108(2):171.

Mauno, S, Kinnunen, U \& Ruokolainen, M. 2007. Job demands and resources of work engagement: A longitudinal study. Journal of Vocational Behaviour 70:149-171.

Mayer, C, Louw, L \& Louw, MJ. 2010. Sense of coherence and organizational commitment. A case study in a selected South African parastatal. Competitive Paper, $22^{\text {nd }}$ Annual Conference of the Southern African Institute for Management Scientists (SIMAS), Port Alfred, South Africa, 12-15 September.

Meyer, JP \& Allen, NJ. 1991. A three-component conceptualisation of organisational commitment. Human Resource Management Review 1(1):61-89.

Meyer, JP \& Allen, NJ. 1997. Commitment in the workplace: Theory, research and application. London: Sage.

Meyer, JP, Allen, N \& Smith, C. 1993. Commitment to organisations and occupations: Extension and test of a three-component conceptualization. Journal of Applied Psychology 78(4):538-551.

Meyer, JP, Stanley, DJ, Herscovitch, L \& Topolnytsky, L. 2002. Affective, continuance, and normative commitment to the organization: A meta-analysis of antecedents, correlates, and consequences. Journal of Vocational Behavior 61(1):20-52.

Narainsamy, KN \& Van der Westhuizen, S. 2013. Work related wellbeing: Burnout, work engagement, occupational stress and job satisfaction within a medical laboratory setting. Journal of Psychology in Africa 23(3):467-474.

Nazir, T, Shah, SFH \& Zaman, K. 2013. The relationship between job satisfaction and remuneration in Pakistan: Higher education institutes perspectives. Academia 5(2):39-42.

Nunnally, JC. 1978. Psychometric theory. New York, NY: McGraw-Hill. 
Obi-Nwosu, H, Chiamaka, J \& Tochukwu, O. 2013. Job characteristics as predictors of organizational commitment among private sector workers in Anambra state, Nigeria. International Journal of Asian Social Science 3(2):482-491.

Oshagbemi, T. 2000. Is length of service related to the level of job satisfaction? International Journal of Social Economics 27(3):213-226.

Peng, J, Li, D, Zhang, Z, Tian, Y, Miao, D, Xiao, W \& Zhang, J. 2014. How can core self-evaluations influence job burnout? The key roles of organizational commitment and job satisfaction. Journal of Health Psychology, February:1-10. Available at: DOI: 10.1177/1359105314521478.

Pillay, R. 2008. Work satisfaction of medical doctors in the South African private health sector. Journal of Health Organisation and Management 22(3):254-268.

Pop, C \& Barkhuizen, N. 2010. The relationship between skills training and retention of graduate interns in a South African information, communication and technology company. Literacy Information and Computer Education Journal 1(2) Available at: http://www.infonomicssociety.org/LICEJ/The\%20Relationship\%20between\%20Skills \%20Training\%20and\%20Retention\%20of\%20Graduate $\% 20$ Interns $\% 20$ in $\% 20$ a $\% 20$ South\%20Africa\%20Information_Communication\%20and\%20Technology\%20Comp any.pdf (accessed on 10 October 2014).

Radler. BT \& Ryff, CD. 2010. Who participates? Accounting for longitudinal retention in the MIDUS national study of health and well-being. Journal of Aging and Health 22(3):307-331.

Rahman, M \& Iqbal, F. 2013. A comprehensive relationship between job satisfaction and turnover intention of private commercial bank employees' in Bangladesh. International Journal of Science and Research 2(6):17-23.

Raina, R \& Roebuck, DB. 2014. Exploring cultural influence on managerial communication in relationship to job satisfaction, organizational commitment, and the employees' propensity to leave in the insurance sector of India. International Journal of Business Communication April 16. Available at: DOI: 10.1177/ 2329488414525453.

Rasool, F \& Botha, CJ. 2011. The nature, extent and effect of skills shortages on skills migration in South Africa. South African Journal of Human Resource Management 9(1):287-298.

Rothausen, TJ \& Henderson, KE. 2014. What is the meaning of this? Identity and wellbeing in sensemaking about retention and turnover. Available at: http://ir.stthomas.edu/cgi/viewcontent.cgi?article-1002\&context=ocbmgtwp. (accessed on 14 October 2014).

Rothmann, S. 2003. Burnout and engagement: A South African perspective. South African Journal of Industrial Psychology 29(4):16-25.

Rothmann, S. 2008. Job satisfaction, occupational stress, burnout and work engagement as components of work-related wellbeing: Empirical research. SA Journal of Industrial Psychology 34(3):11-16.

Rutherford, B, Boles, JG, Hamwi, A, Madupalli, R \& Rutherford, L. 2009. The role of the seven dimensions of job satisfaction in salespersons' attitudes and behaviors. Journal of Business Research 62(11):1146-1151.

Saks, AM. 2006. Antecedents and consequences of employee engagement. Journal of Managerial Psychology 21:600-619. 
Salanova, M., Agut, S, \& Peiro, JM. 2005. Linking organizational resources and work engagement to employee performance and customer loyalty: The mediation of service climate. Journal of Applied Psychology 90(6):12-17.

Salanova, M \& Schaufeli, WB. 2008. A cross-national study of work engagement as a mediator between job resources and proactive behaviour. The International Journal of Human Resource Management 19:116-131.

Savaneviciene, A \& Stankeviciute, Z. 2011. Human resources management practices linkage with organisational commitment and job satisfaction. Economics and Management 16:921-927.

Schaufeli, WB \& Bakker, AB. 2004. Job demands, job resources, and their relationship with burnout and engagement: A multi-sample study. Journal of Organisational Behaviour 25(3):293-309.

Schaufeli, WB, Salanova, M, González-Roma, V \& Bakker, AB. 2002. The measurement of engagement and burnout: A two-sample confirmatory factor analytic approach. Journal of Happiness Studies 3:71-92.

Sears, LE, Shi, Y, Coberley, CR \& Pope, JE. 2013. Overall well-being as a predictor of health care, productivity and retention outcomes in a large employer. Population Health Management 16(6):397-405.

Shaughnessy, JJ, Zechmeister, EB \& Zechmeister, JS. 2003. Research methods in psychology. 6th edition. New York, NY: McGraw-Hill.

Siebenhagen, C, Pienaar, J \& Els, C. 2011. Management of employee wellness in South Africa: Employer, service provider and union perspectives. South African Journal of Human Resource Management 9(1):1-14. Available at: DOI: 10.4102/sajhrm.v9i1.305.

Simons, JC \& Buitendach, JH. 2013. Psychological capital, work engagement and organisational commitment amongst call centre employees in South Africa. SA Journal of Industrial Psychology 39(2):1-12.

Siu OL. 2002. Occupational stressors and wellbeing among Chinese employees: The role of organisational commitment. Applied Psychology: An International Review 5:527-544.

Spector, PE. 1997. Job satisfaction: Application, assessment, causes, and consequences. Thousand Oaks, CA: Sage.

Spector, PE. 2008. Industrial and organisational behaviour. $5^{\text {th }}$ edition. Hoboken, NJ: Wiley.

SPSS Inc. 2014. SPSS version 12.0 for the Microsoft Windows platform. Chicago, IL: SPSS Inc.

Statistics South Africa. 2015. Find statistics. Available at: http://beta2.statssa.gov.za/? page_id=593 (accessed on 1 February 2015).

Stevn. HS. 2002. Practicallv sianificant relationships between two variables. SA Journal of Industrial Psychology 28(3):10-15.

Storm, K \& Rothmann, S. 2003. A psychometric analysis of the Utrecht Work Engagement Scale in the South African Police Service. South African Journal of Industrial Psychology 2(4):62-70. 
Strümpfer, DJW \& De Bruin, GP. 2009. Antonovsky's sense of coherence and job satisfaction: Meta-analyses of South African data. South African Journal of Industrial Psychology 35(1):87-96.

Suliman, AM \& Iles, PA. 2000. The multi-dimensional nature of organisational commitment in a non-western context. Journal of Management Development 19(1):71-82.

Van Dyk, J \& Coetzee, M. 2012. Retention factors in relation to organisational commitment in medical and information technology services. SA Journal of Human Resource Management 10(2):1-11.

Vecina, ML, Chacó, F, Sueiro, M \& Barrón, A. 2012. Volunteer engagement: Does engagement predict the degree of satisfaction among new volunteers and the commitment of those who have been active longer? Applied Psychology 61(1): 130-148. Available at: DOI/10/111/apps,2012.61.issue-1/issuetoc.

Youssef, CM \& Luthans F. 2007. Positive organisational behaviour in the workplace: The impact of hope, optimism, and resilience. Journal of Management 33(5): 774-800.

Xanthopoulou, D, Bakker, AB, Demerouti, E \& Schaufeli, WB. 2009. Reciprocal relationships between job resources, personal resources, and work engagement. Journal of Vocational Behavior 74(3):235-244. 